\title{
IMPACT OF FOREST SOIL ENRICHMENT WITH NITROGEN FERTILIZER ON THROUGHFALL AND SOIL WATER CHEMICAL PROPERTIES
}

\author{
Ilze Kārkliṇa ${ }^{1,2}$, Jeḷena Stola ${ }^{1}$ \\ ${ }^{1}$ Latvian State Forest Research Institute 'Silava', Latvia \\ ${ }^{2}$ University of Latvia, Latvia \\ ilze.karklina@silava.lv
}

\begin{abstract}
A demand for wood resources is increasing. In addition to drainage and appropriate regeneration and thinning, the forest soil fertilization may increase the future harvest rates. Therefore, the improved growth of forest stands raises in priority among the research topics related to forestry. The objective of the study is to evaluate the impact of nitrogen fertilizer on soil water and throughfall water chemical composition to elaborate recommendations for the forest fertilization. The trials were conducted in a birch stand and in three coniferous stands. Nitrogen containing mineral fertilizer (ammonium nitrate) was distributed in the study sites, while the control plots were left without any treatment. The water samples were collected a season before and a season after the soil treatment. The $\mathrm{pH}$ level, total nitrogen, potassium and phosphate were determined in throughfall and soil water samples. The chemical properties of throughfall water differed depending on the forest stand type. The concentration of nitrogen was higher in throughfall water samples collected from the birch stand. The mean concentration of total nitrogen was $1.6 \pm$ $0.3 \mathrm{mg} \mathrm{L}^{-1}$ in the throughfall water samples from the birch stand compared to $1.03 \pm 0.11 \mathrm{mg} \mathrm{L}^{-1}$ in the throughfall water samples from the coniferous stands. Although the forest soil was enriched with the nitrogen fertilizer, there was a significant increase in concentrations of potassium and phosphate in soil water samples from certain stands. It can be explained with changes in $\mathrm{pH}$ level that occurred after the forest soil treatment with ammonium nitrate. There was also a significant increase in total nitrogen concentrations in soil water samples at the depth of $30 \mathrm{~cm}$ from the treated plots of the coniferous stands $-15 \pm 6 \mathrm{mg} \mathrm{L}^{-1}$, compared to $1.5 \pm 0.03 \mathrm{mg} \mathrm{L}^{-1}$ in the samples from the control plots. However, the concentrations decreased within two months and remained at a steady rate - slightly above the control level.
\end{abstract}

Key words: forest fertilization, ammonium nitrate, water chemistry.

\section{Introduction}

According to the studies, in particular, the agriculture and climate change related research, the ability to control the nitrogen cycle has been recognized as a substantial factor in the future of mankind. The usage of synthetic fertilizer has rapidly increased in the $20^{\text {th }}$ century. Consequently, nitrate pollution and nitrous oxide as one of the greenhouse gas are considered to be the result of impacted nitrogen cycle (Stein \& Klotz, 2016). However, it is commonly discussed that an increased growth of forest stand may facilitate climate change mitigation by removal of carbon dioxide in biomass (Houle \& Moore, 2019). In addition, extra increment, induced by fertilizer, helps to meet the increasing demand for woody biomass. Initial fertilization, applied during the period of plantation, may increase the stem volume of Norway spruce (Picea abies (L.) H.Karst.) by 17\% (Jansons et $a l ., 2016)$. Therefore, the forest soil enrichment with nitrogen containing fertilizer is an essential research topic related to the forestry and water chemistry.

Boreal coniferous forests are acknowledged as one of the most nitrogen limited ecosystems (Houle \& Moore, 2019). In addition to the economic impact, forest fertilization is an effective measure to reduce greenhouse gas emissions. It is possible to achieve maximum additional radial increment in the $10^{\text {th }}$ year after the application of ammonium nitrate. Theoretically it can be done in about $0.2 \%$ of state forests annually (Petaja et al., 2018). Other research results show that, depending on the forest type under similar climatic regimes, simulated elevated rates of atmospheric nitrogen deposition (stands were treated with 50 or $150 \mathrm{~kg} \mathrm{~N} \mathrm{ha}^{-1} \mathrm{yr}^{-1}$ ) may promote losses of nitric oxide from forest soil as a result of nitrification (Venterea et al., 2003). It has been reported that since 1990s the rate of nitrogen atmospheric deposition in Europe has declined. Research findings report decrease in elevated nitrate concentrations in soil solution and mostly lower nitrogen deposition in the Eastern Europe (Schmitz et al., 2019). However, if the soil treatment with nitrogen containing fertilizer is intended, the capacity of plant uptake must be considered. It is also important because nitrogen saturation may affect the tree health (Houle \& Moore, 2019). In this context nitrates in soil solution indicate nitrogen availability in excess of biotic demand (Schmitz et al., 2019).

Throughfall is a part of precipitation that filters through canopy and has an impact on soil water chemical quality. While falling through canopy, precipitation changes in terms of water quality and quantity. There is a difference in chemical composition of throughfall depending on dominant trees, namely, coniferous or deciduous trees (Tērauda, 2008). The chemical composition of throughfall may be impacted also by insect excreta (Reynolds \& Hunter, 2004). Water $\mathrm{pH}$ level of throghfall from coniferous stand is 
lower than the $\mathrm{pH}$ level of an open field precipitation (Tērauda, 2008). The amounts of nutrients that reach soil with throughfall usually are elevated, especially potassium (Pallardy \& Kozlowski, 2008). Therefore, throughfall is also an important aspect to consider by estimating the impact on soil water properties. Nutrient, among them nitrogen and potassium, input in canopy occur through deposition - wet, dry and cloud deposition (Reynolds \& Hunter, 2004).

To estimate the impact of fertilizer on forest soil solution and to distinguish any natural variations in chemical properties from the treatment impact, data should be compared from both control and fertilized plot (Stuanes, Kjønaas, \& van Miegroet, 1995). In the experimental site of mature spruce, ammonium nitrate (35 $\mathrm{kg} \mathrm{N} \mathrm{ha}^{-1} \mathrm{yr}^{-1}$ ) was repeatedly applied to $500 \mathrm{~m}^{2}$ plots and after 4 years of the treatment an increase in nitrate concentrations in soil solution was observed. Despite the ascertained nitrate leaching, $92 \%$ of inputs were preserved (Gundersen, 1998). Likewise, in the research related to the response of boreal ecosystem to eight years of ammonium nitrate addition, a high nitrogen retention capacity of two boreal coniferous stands was observed (Houle \& Moore, 2019).

The aim of this study was to estimate the impact of the forest fertilization with ammonium nitrate on soil water and throughfall water chemical properties two years after the soil enrichment.

\section{Materials and Methods}

\section{Study site}

The research was conducted in four forest stands. Two of them are located in the central part and two in the eastern part of Latvia. During 2016, the experimental plots were established in the forest sites managed by the Research forest station (Table 1).

\section{Treatments}

In period May - July, 2017 ammonium nitrate was spread in the experimental plots (Table 2). The fertilizer was applied manually in one pine stand (2110-4) and mechanically in the rest of the stands.

Sampling and analyses

Each of the experimental sites has one control plot and one treatment plot - both located in the same forest stand. Lysimeters and throughfall collectors were installed according to IPC Forests guidelines (Convention on Long Range Transboundary Air Pollution, 2010). Each plot has three pairs of vacuum lysimeters and three throughfall water collectors. The vacuum lysimeters were installed at depths $30 \mathrm{~cm}$ and $60 \mathrm{~cm}$ to collect soil leachate. Rainwater was gathered with throughfall water collectors. Both soil water and throughfall samples were collected once per month. The period of field works was restricted by weather conditions, namely, average daily temperatures. First water samples were collected starting from May and field works lasted till September or October. The parameters determined in the water samples are: $\mathrm{pH}$, $\mathrm{N}_{\text {TOT }} \mathrm{mg} \mathrm{L}^{-1}, \mathrm{~K} \mathrm{mg} \mathrm{L}^{-1}$ and $\mathrm{PO}_{4}^{3-} \mathrm{mg} \mathrm{L}^{-1}$.

Statistical analysis

We used Mann-Whitney test $p$-values to determine the difference in chemical properties of water. The statistical tests were conducted at a 95\% confidence level. The statistical tests were performed in IBM SPSS Statistics 22.

\section{Results and Discussion}

Figure 1 and Figure 2 illustrate changes in $\mathrm{pH}$ level of throughfall. PH level slightly elevates during the summer period and decreases in the autumn. The values vary from 5.8 to $7.3 \mathrm{mg} \mathrm{L}^{-1}$ in the control plots and from 5.3 to $7.6 \mathrm{mg} \mathrm{L}^{-1}$ in the treated plots.

\section{Description of experimental sites}

Table 1

\begin{tabular}{|l|l|l|l|l|l|}
\hline \multicolumn{1}{|c|}{ Forest stand } & \multicolumn{1}{|c|}{ Forest type } & \multicolumn{1}{|c|}{ Age } & \multicolumn{1}{c|}{ Dominant tree type } & \multicolumn{1}{c|}{ Coordinates, $\mathrm{X}$} & \multicolumn{1}{c|}{ Coordinates, $\mathrm{Y}$} \\
\hline $21-49-14$ & Myrtilloso-sphagnosa & 15 & Birch & 56.709612 & 23.755750 \\
\hline $11-18-5$ & Hylocomiosa & 36 & Spruce & 56.736803 & 25.879994 \\
\hline $11-210-5$ & Myrtillosa & 67 & Pine & 56.681789 & 25.989758 \\
\hline $21-10-4$ & Hylocomiosa & 22 & Pine & 56.738765 & 23.719551 \\
\hline
\end{tabular}

Table 2

Treatment in experimental sites

\begin{tabular}{|l|l|l|l|}
\hline Forest stand & $\mathrm{NH}_{4} \mathrm{NO}_{3}, \mathrm{t} \mathrm{ha}^{-1}$ & Area, ha & Month / year \\
\hline $21-49-14$ & 0.44 & 0.18 & 05.2017 \\
\hline $11-18-5$ & 0.44 & 0.80 & 07.2017 \\
\hline $11-210-5$ & 0.44 & 1.50 & 07.2017 \\
\hline $21-10-4$ & 0.44 & 1.62 & 06.2017 \\
\hline
\end{tabular}




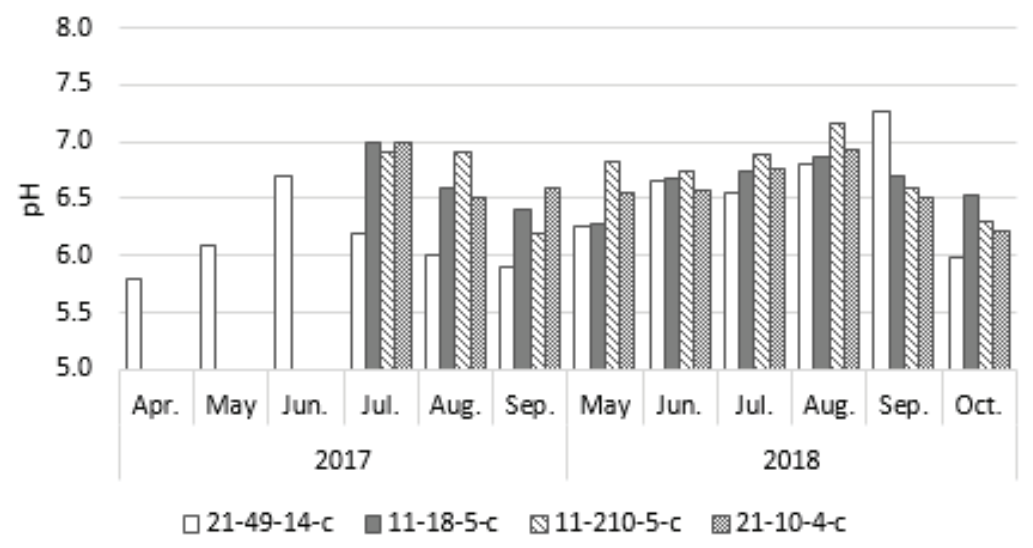

Figure 1. PH level in throughfall collected from control plots.

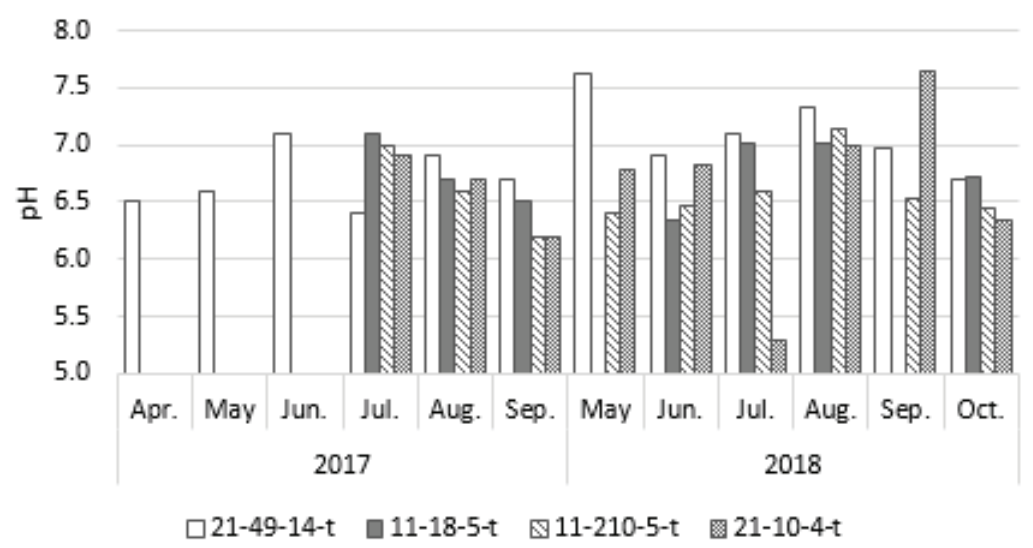

Figure 2. PH level in throughfall collected from treated plots.

The observed seasonal changes in $\mathrm{pH}$ level are related to the impact of the canopy on precipitation parameters. Namely, while flowing through the canopy, rainfall interacts with ions of leaves or needles. As a result, the average $\mathrm{pH}$ level of throughfall is higher than $\mathrm{pH}$ level of open field precipitation (Tērauda, 2008).

Figure 3 and Figure 4 illustrate changes in the total nitrogen concentrations of throughfall. Total nitrogen concentration values vary from 0.21 to $6.80 \mathrm{mg} \mathrm{L}^{-1}$ in the control plots and from 0.33 to $3.04 \mathrm{mg} \mathrm{L}^{-1}$ in the treated plots, but the mean values are $1.3 \pm 0.2 \mathrm{mg} \mathrm{L}^{-1}$ in the control plots and $1.1 \pm 0.1 \mathrm{mg} \mathrm{L}^{-1}$ in the treated plots.

After the forest soil enrichment with ammonium nitrate, there was no significant increase in the total nitrogen concentrations in water samples from fertilized plots. Elevated total nitrogen concentrations detected in May, June and July samples could be affected by pollen, needles or leaves that have accidentally fallen into the collectors. Birch is the dominant tree species of the forest stand 21-49-14. Since chemical properties of leaves differ from needles (Tērauda, 2008), the Figure 3 and Figure 4 elucidate the difference in total nitrogen concentrations between throughfall collected from the coniferous and the deciduous stands. Likewise, there were higher potassium and phosphate concentrations in the samples from the birch stand. The mean concentrations of potassium were $3.6 \pm 0.6 \mathrm{mg} \mathrm{L}^{-1}$ in the samples from the birch stand and $2.1 \pm 0.2 \mathrm{mg} \mathrm{L}^{-1}$ in the samples from the coniferous stands. Similarly, the mean concentrations of phosphate were $0.19 \pm$ $0.04 \mathrm{mg} \mathrm{L}^{-1}$ and $0.10 \pm 0.03 \mathrm{mg} \mathrm{L}^{-1}-$ from the birch and the coniferous stands, respectively.

Considering that nutrient status in soil may diversify depending on the forest type, soil water sample results of chemical analyses were divided into two groups. The first group consisted of data collected from the forest stands on dry mineral soil (11-18-5, 11-210-5 and 21-10-4) - Hylocomiosa and Myrtillosa, respectively. The second group was formed of data collected from the birch forest stand (21-49-14) on wet mineral soil - Myrtilloso-sphagnosa.

Figure 5, Figure 6, Figure 7 and Figure 8 illustrate the possible impact of ammonium nitrate fertilizer on soil water chemical properties. In the forest stands on dry mineral soil we observed an elevated $\mathrm{pH}$ level in the soil samples from the treated plots. It has also been reported on increased $\mathrm{pH}$ level in soil solution after the application of nitrogen containing mineral fertilizer (Aber et al., 1989). We also observed a rapid increase in the total nitrogen concentrations in 


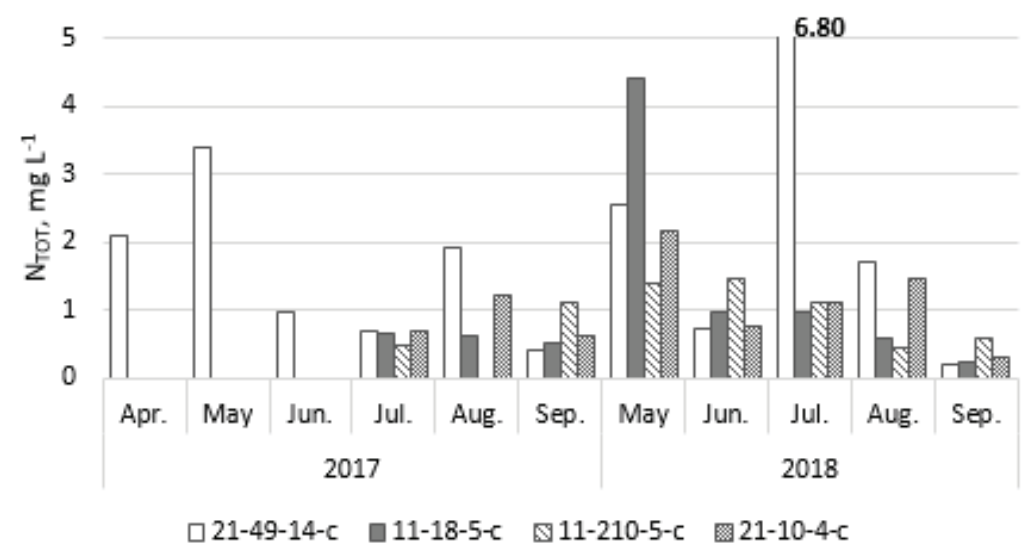

Figure 3. $\mathrm{N}_{\mathrm{TOT}} \mathrm{mg} \mathrm{L}^{-1}$ concentrations in throughfall collected from control plots.

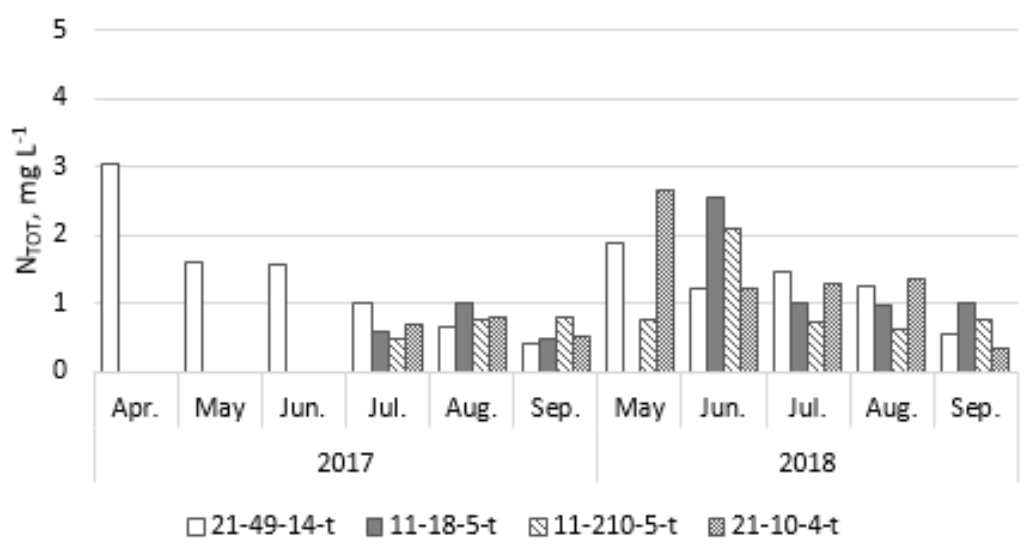

Figure 4. $\mathrm{N}_{\mathrm{TOT}} \mathrm{mg} \mathrm{L}^{-1}$ concentrations in throughfall collected from treated plots.

soil water samples from the coniferous stands on dry mineral soil. The concentrations decreased within two months. There was also a slight increase in total nitrogen concentrations in the soil water samples from the birch stand on wet mineral soil; however, the concentrations were relatively low. In all data groups, larger data variation was observed in the soil water samples collected from $30 \mathrm{~cm}$ depth rather than from $60 \mathrm{~cm}$ depth (Stuanes, Kjønaas, \& van Miegroet, 1995).

In both experimental groups, we observed a statistically significant increase in total nitrogen

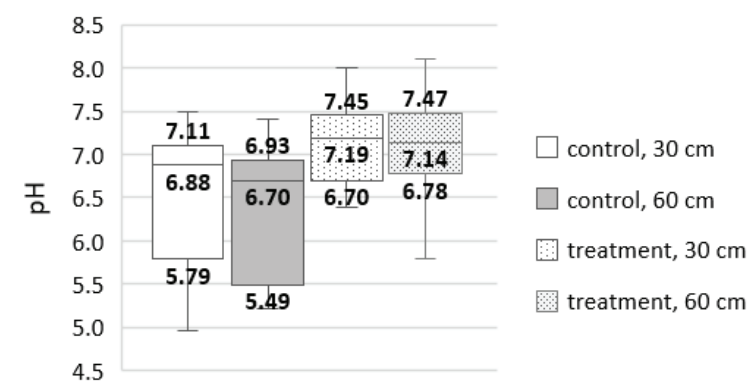

Figure 5. PH level in soil water collected from stands 11-18-5, 11-210-5, 21-10-4. concentrations in soil water samples from the treated plots (Table 3 ). The mean concentrations were $1.5 \pm$ $0.3 \mathrm{mg} \mathrm{L}^{-1}$ at the depth of $30 \mathrm{~cm}$ and $1.4 \pm 0.3 \mathrm{mg} \mathrm{L}^{-1}$ at the depth of $60 \mathrm{~cm}$ in the soil water samples from the untreated control plots compared to $15 \pm 6 \mathrm{mg} \mathrm{L}^{-1}$ at the depth of $30 \mathrm{~cm}$ and $5 \pm 1 \mathrm{mg} \mathrm{L}^{-1}$ at the depth of $60 \mathrm{~cm}$ in the samples from the treated plots of the coniferous stands. The total nitrogen concentration increased more moderately in the soil water samples from the treated plot of the birch stand $-7.3 \pm 0.9 \mathrm{mg}$ $\mathrm{L}^{-1}$ at the depth of $30 \mathrm{~cm}$ and $5.4 \pm 0.5 \mathrm{mg} \mathrm{L}^{-1}$ at the depth of $60 \mathrm{~cm}$ compared to concentrations in the

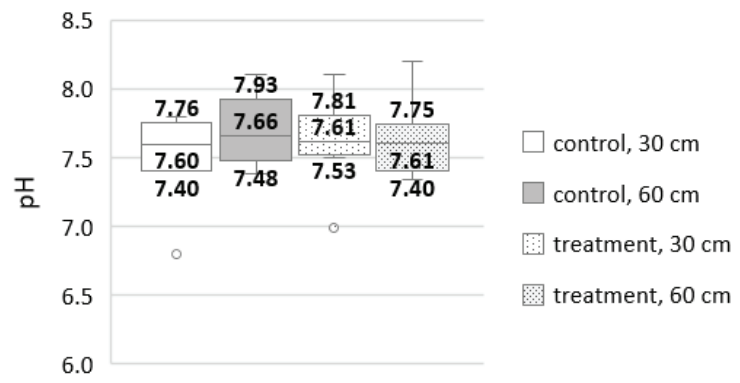

Figure 6. PH level in soil water collected from stand 21-49-14. 


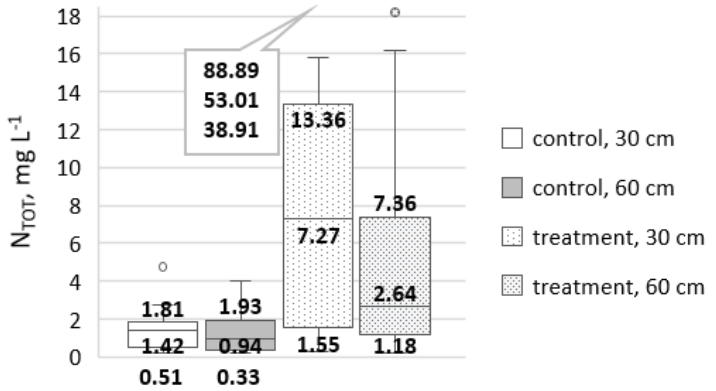

Figure 7. Nitrogen $\left(\mathrm{N}_{\mathrm{TOT}} \mathrm{mg} \mathrm{L}^{-1}\right)$ concentration in soil water collected from stands 11-18-5, 11-210-5, 21-10-4.

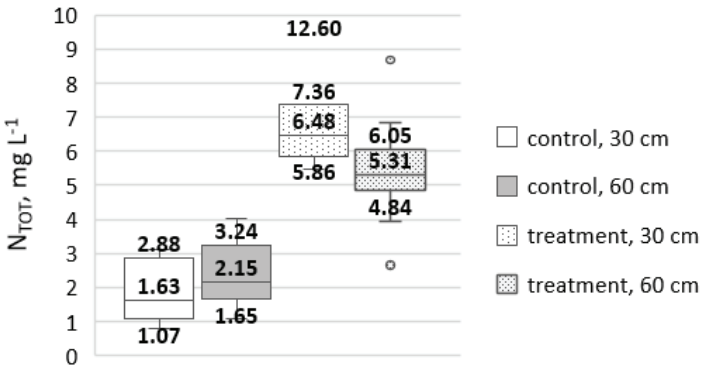

Figure 8. Nitrogen $\left(\mathrm{N}_{\mathrm{TOT}} \mathrm{mg} \mathrm{L}^{-1}\right)$ concentration in soil water collected from stand 21-49-14.

\section{Mann-Whitney test p-values for soil water chemical parameters}

\begin{tabular}{|l|l|l|l|l|}
\hline \multirow{2}{*}{ Parameter } & \multicolumn{2}{|l|}{ Forest stands 11-18-5, $21-10-4,11-210-5$} & \multicolumn{2}{l|}{ Forest stand 21-49-14 } \\
\cline { 2 - 5 } & $30 \mathrm{~cm}$ & $60 \mathrm{~cm}$ & $30 \mathrm{~cm}$ & $60 \mathrm{~cm}$ \\
\hline $\mathrm{pH}$ & $0.017^{*}$ & $0.006^{*}$ & 0.682 & 0.503 \\
\hline $\mathrm{K}, \mathrm{mg} \mathrm{L}^{-1}$ & 0.951 & 0.771 & $0.003^{*}$ & 0.736 \\
\hline $\mathrm{N}_{\mathrm{TOT}}, \mathrm{mg} \mathrm{L}^{-1}$ & $0.004^{*}$ & $0.023^{*}$ & $0.002^{*}$ & $0.001^{*}$ \\
\hline $\mathrm{PO}_{4}^{3-}, \mathrm{mg} \mathrm{L}^{-1}$ & $0.004^{*}$ & $0.003^{*}$ & 0.206 & 0.860 \\
\hline
\end{tabular}

* - a statistically significant difference

samples from the control plot $-1.8 \pm 0.3 \mathrm{mg} \mathrm{L}^{-1}$ at the depth of $30 \mathrm{~cm}$ and $2.4 \pm 0.3 \mathrm{mg} \mathrm{L}^{-1}$ at the depth of $60 \mathrm{~cm}$. There was also a statistically significant increase in potassium concentrations in the soil water samples from the birch stand and a significant decrease in phosphate concentrations in the water samples from the coniferous stands. The mean concentrations of potassium at the depth of $30 \mathrm{~cm}$ were $0.26 \pm 0.04 \mathrm{mg}$ $\mathrm{L}^{-1}$ in the soil water samples from the control plot and $0.38 \pm 0.06 \mathrm{mg} \mathrm{L}^{-1}$ in the samples collected from the treated plot of the birch stand. The concentrations of phosphate were $0.043 \pm 0.006 \mathrm{mg} \mathrm{L}^{-1}$ at the depth of $30 \mathrm{~cm}$ and $0.06 \pm 0.03 \mathrm{mg} \mathrm{L}^{-1}$ at the depth of $60 \mathrm{~cm}$ in the soil water samples from the untreated control plots compared to $0.019 \pm 0.004 \mathrm{mg} \mathrm{L}^{-1}$ at the depth of $30 \mathrm{~cm}$ and $0.013 \pm 0.003 \mathrm{mg} \mathrm{L}^{-1}$ at the depth of $60 \mathrm{~cm}$ in the samples from the treated plots of the coniferous stands.

\section{Conclusions}

1. Chemical parameters of throughfall do not indicate any impact of the nitrogen fertilizer. However, changes in throughfall chemical composition show the possible impact of pollen or needles that have fallen into collectors.

2. Two months after the ammonium nitrate spreading there was a short term increase in total nitrogen concentrations in the soil water samples collected in the treated plots. The concentrations diminished within two months, but stayed steady during the remaining monitoring period; however, relatively higher compared to the control plot.

3. In order to characterize more precisely the distributed fertilizer leaching, the chemical parameters of soil water samples should be statistically analyzed along with chemical properties of soil and needle samples.

\section{Acknowledgements}

The study is implemented within the scope of the memorandum between the Joint Stock Company 'Latvia state forests' and LSFRI Silava on 'Collaboration in scientific research' from October 11, 2011. The research was conducted within the scope of the Joint Stock Company 'Latvia state forests' research project 'Research program on forest fertilization' (2016-2021).

\section{References}

1. Aber, J.D., Nadelhoffer, K.J., Steudler, P., \& Melillo, J.M. (1989). Nitrogen Saturation in Northern Forest Ecosystems. BioScience, 39(6), 378-286.

2. Convention on Long Range Transboundary Air Pollution (Ed.). (2010). ICP forests manual on methods and criteria for harmonized sampling, assessment, monitoring and analysis of the effects of air pollution 
on forests: international co-operative programme on assessment and monitoring of air pollution effects on forests (ICP forests). Hamburg: Johann Heinrich von Thünen Inst., Inst. for World Forestry.

3. Gundersen, P. (1998). Effects of enhanced nitrogen deposition in a spruce forest at Klosterhede, Denmark, examined by moderate NH4NO3 addition. Forest Ecology and Management, 101(1-3), 251-268. DOI: 10.1016/S0378-1127(97)00141-2.

4. Houle, D., \& Moore, J.-D. (2019). Soil solution, foliar concentrations and tree growth response to 8 years of ammonium-nitrate additions in two boreal forests of Quebec, Canada. Forest Ecology and Management, 437, 263-271. DOI: 10.1016/j.foreco.2019.01.024.

5. Jansons, Ā., Matisons, R., Krišāns, O., Džeriņa, B., \& Zeps, M. (2016). Effect of initial fertilization on 34-year increment and wood properties of Norway spruce in Latvia. Silva Fennica, 50(1), article ID 1346. 8. DOI: $10.14214 /$ sf.1346.

6. Pallardy, S.G., \& Kozlowski, T.T. (2008). Physiology of woody plants (3 ${ }^{\text {rd }}$ ed). Amsterdam; Boston: Elsevier.

7. Petaja, G., Okmanis, M., Makovskis, K., Lazdina, D., \& Lazdiňš, A. (2018). Forest Fertilization: Economic Effect and Impact on GHG Emissions in Latvia. BALTIC FORESTRY, 24(1), 8.

8. Reynolds, B.C., \& Hunter, M.D. (2004). Nutrient Cycling. In Forest Canopies (pp. 387-396). DOI: 10.1016/B978-012457553-0/50025-3.

9. Schmitz, A., Sanders, T.G.M., Bolte, A., Bussotti, F., Dirnböck, T., Johnson, J., \& de Vries, W. (2019). Responses of forest ecosystems in Europe to decreasing nitrogen deposition. Environmental Pollution, 244, 980-994. DOI: 10.1016/j.envpol.2018.09.101.

10. Stein, L.Y., \& Klotz, M.G. (2016). The nitrogen cycle. Current Biology, 26(3), 94-98. DOI: 10.1016/j. cub.2015.12.021.

11. Stuanes, A.O., Kjønaas, O.J., \& van Miegroet, H. (1995). Soil solution response to experimental addition of nitrogen to a forested catchment at Gårdsjön, Sweden. Forest Ecology and Management, 71(1-2), 99110. DOI: 10.1016/0378-1127(94)06087-Y.

12. Tērauda, E. (2008). Ķ̄imisko vielu plūsmas Latvijas priežu mežu ekosistēmās (Flows of chemical substances in Latvian pine forests ecosystems). Diss. University of Latvia, Riga (Latvia), Faculty of Geography and Earth Sciences, Dept. of Environmental Science (in Latvian)

13. Venterea, R.T., Groffman, P.M., Verchot, L.V., Magill, A.H., Aber, J.D., \& Steudler, P.A. (2003). Nitrogen oxide gas emissions from temperate forest soils receiving long-term nitrogen inputs. Global Change Biology, 9(3), 346-357. DOI: 10.1046/j.1365-2486.2003.00591.x. 